\title{
THE BIRD THAT NEVER WAS
}

\author{
VICTOR C. FRIESEN, P.O. Box 65, Rosthern, Saskatchewan. SOK 3RO
}

I wish to record a bird sighting that I made many years ago - in mid-July of 1947 - when my cousin and I were camping at the South Saskatchewan River. I was 14 years old then, and I am sure of the time because I had taken some snapshots of our outing and dated the pictures. The sighting occurred at Gabriel's Crossing, east of Rosthern.

I write of the incident now with some trepidation, knowing that I am putting my credibility on the line. I do so after publishing some ten articles previously in Blue Jay and having just this year published a book by a university press on the American naturalist Henry Thoreau. Perhaps this article may be considered a kind of companion piece to one which appeared in this journal two years ago about another bird that "wasn't". ${ }^{4}$

At the time I had no field guide to help me in identifying the bird, but the colour patterns were so simple and so striking that there could be no quandary about them. I had got up early that morning and was beginning to prepare breakfast outside the tent. Then a strange bird alighted on a branch poking into the natural clearing in which the tent was pitched. (Our camp was on a "bench" above the west shoreline, surrounded for the most part by willow, with some balsam poplar and white birch.)

The bird was in plain view no more than $3 \mathrm{~m}$ from me. The sun, although hidden by clouds, was behind me. It may be that the bird had not expected to see anything unusual in the clearing. At any rate, we both eyed each other for a good minute or so before it flew away. The bird was entirely black except for its scarlet-red head. For size, general configuration and body posture, I could not better describe it than saying it looked like a Brown- headed Cowbird, only that its brown head was red - a red-headed cowbird, if you like.

That I should meet with an unusual bird at the river was not surprising to me then. I knew that the river's wooded slopes supported birdlife which was not found in the open parkland with which I was familiar just a few kilometres away. It was at about this time that I had seen an equally colourful bird new to me in a riverbank ravine, the Rufous-sided Towhee with its black, white and rufous plumage. Only later was I able to identify if form a sketch appearing in the Mark Trail comic strip by Ed Dodd.

With the bird seen at the campsite, I had no resource to go to. I knew a fair number of bird species from illustrations in outdoor magazines at our home or in school science textbooks, but the oneroomed rural school I attended had no books on birds at all. So I filed this sighting away in my mind, thinking that some day in the future I would have access to a book whose colour plates would vividly portray my bird,

In the meantime I had me a "mystery" bird. In this regard I was like Thoreau who would become my main object of research in adult life. He, a century earlier, had had three mystery birds: his "seringo-bird" (usually the Savannah Sparrow), his "evergreen-forest bird" (probably the Black-thoated Green Warbler) and his "night-warbler" (almost certainly the Ovenbird). ${ }^{2}$

Of course, had Thoreau had a good set of binoculars and a modern-day field guide, these confusions would not have existed - although he liked to maintain, in his well-known Walden, that we require that in nature "all things be mysterious 


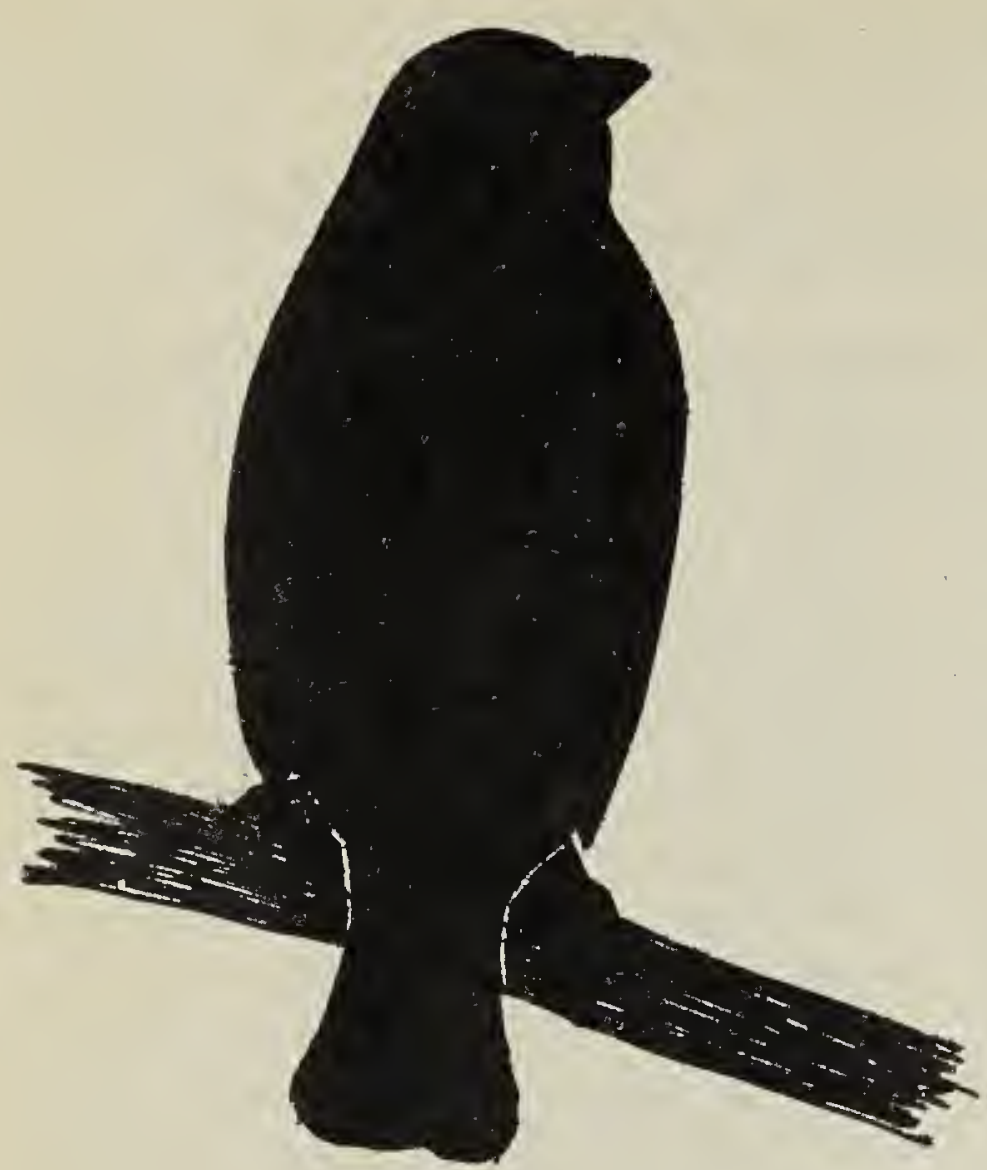

and unexplorable". ${ }^{13}$ Just as he gives chase to the Common Loon in the "Brute Neighbors" chapter of his book, that bird, which represents the mystery, should ever elude him. Thoreau never did positively identify his "night-warbler", and his friend Ralph Waldo Emerson advised him not to try, for nature would then hold for him less mystery.

I, however, was still trying to identify my mystery bird. Living on a farm in the 1940 s was different from what it is nowadays. I was taking my high school by correspondence courses at our livingroom table, and since I did not bother to have my assignments corrected (it was cheaper that way), I lacked even that bit of contact with the city world. So far as visiting a city and its libraries where there might be bird books, that simply did not happen. But three years after my sighting of the bird in question, I sent for Peterson's Field Guide to the Birds, ${ }^{7}$ after seeing it described in a nature magazine. I ordered it directly from the Canadian distributor.

I was somewhat taken aback when on paging through this "Second Revised and
Enlarged Edition", my bird was nowhere to be found. I realized the guide covered eastern North America, up to roughly the 100th meridian so that all of Saskatchewan was not included. The book was nonetheless a treasure trove for me, and with it I was adding a dozen new birds to my life list (which I started then) on the next few "bird-hikes" I took. My mystery bird had to take a backseat to all the other birds I was identifying. And of course I had still the varied interests of most teenagers to fill up my spare moments: sports, music, art and literature.

Then in 1956 I spent a winter in British Columbia, and in preparation for going there, I purchased Perterson's Field Guide to Western Birds. ${ }^{6}$ At long last I would be able to name the bird I had seen almost a decade before. But my bird was nowhere illustrated, although again I had many new birds to identify. My use of this first edition (1941), incidentally, had its amusing sidelight. Most of the plates were not coloured, and the author had so religiously stressed the birds' black-andwhite patterns as seen from a distance (this idea credited to Ernest Thompson Seton but suggested even earlier by Thoreau in his journal) that in some cases I had to squint in order to block out a bird's rich colouring or else stealthily back away from the bird before I could make sure of the identification.

So my bird (I had become quite possessive of it by this time) was not a North American resident in good standing. Was it perhaps a wanderer from another continent or from tropical regions? The notion of a bird of this type arriving in mid-continent did not seem very probable. Pough's three Audubon bird guides, ${ }^{10} 1112$ which give a good coverage of wanderers to Canada and the United States, did not refer to any black bird with a red head.

My check of the Field Guide to the Birds of Britain and Europe ${ }^{8}$ turned up nothing either. Perusal of the Field Guide to Mexican Birds ${ }^{9}$ revealed nothing closer 
than a Crimson-collared Tanager (black face and red rump), a Red-headed Tanager (olive and yellow body), and a tiny Red-capped Manakin (yellow "trousers").

I then began to consider all possibilities, no matter how far-fetched, in order to identify the bird. I could readily dismiss the suggestion that it had been spraypainted by some biologist away back in 1940 s (Cf. Robert Nero's spray painting the tails of Great Gray Owls orange or green ${ }^{3}$.)

Another possibility was that the bird was some freak in nature, a mutant, briefly seen and never to be seen again. For precedence there was one classic case of a somewhat related incident, pertaining to botany and involving the pioneer botanists, John and Willian Bartram. ${ }^{1}$ In their day much of America's flora and fauna was new to science, and on a botanizing trip to the Deep South in 1765 , they discovered in the southeastern mountains of Georgia, above the Altamaha River, a slender tree with the scarlet leaves of autumn but still bearing camellia-like white blossoms. It was a unique species, and John Bartram named it Franklinia altamaha for his closest friend Benjamin Franklin. They took some seedlings back to Pennsylvania, which did well under cultivation. In 1790 when William was again in the area, he collected more specimens. But that was the last time, almost 200 years ago, that the tree has been seen growing in the wild. It simply does not exist any more - except as descendants from the Bartrams' collection.

In my own situation I had no concrete evidence whatsoever, and I could not think myself so favoured as to be an exclusive witness to a unique phenomenon. Of course there are some unusual plumage variations in individual species - one Pacific race of the Yellow bellied Sapsucker has a red head, for example; however, my bird was definitely not a woodpecker.
Then there are two specific kinds of plumage variations, albinoism and melanism - but, I wondered, could there be "reddism" too and that on a black bird's head? My mind boggled at the thought. Nonetheless, I considered the likely species where some form of "ism" might account for what I had seen perhaps a melanistic tanager (Western or Scarlet)? But then - I paused for comic relief - why not a tanager fresh from a mudbath? I seemed to be at a dead end.

Finally I grasped at the possibility of a hybrid. Pearson's Birds of America speaks of the sex life of Brown-headed Cowbirds as being "free and untrammeled", with the birds conferring "their favours more or less generally". The females receive male attention "with generous impartiality". This, it should be noted, is among consenting adult cowbirds, that is, within the species. Of the Redwinged Blackbird, Birds of America says that the male sometimes mates "with several wives" - again within the species. ${ }^{5}$ Now . . . if this promiscuity were somehow extended between the two species (my imagination seemed to be running away with me) - if the "red" of a redwing's epaulet were somehow transferred to a cowbird's brown head.

More mind bogglement!

And there is yet an ultimate possibility, an explanation for the mystery bird. It involves a consideration that more than one naturalist has had to face in his birdwatching career - and that is a realization that he may have erred in his observation, that he just did not know what he saw. Still, when I think back to my sighting in 1947 , I cannot discount it because of unusual lighting or far distance or indistinct colour markings. Although I have treated the incident in a somewhat humourous fashion, the image in my mind is as clear today as it was when I made the original observation 37 years ago

1 EIFERT, V.S. 1965. Tall trees and far horizons. Dodd, Mead, New York. 301 $\mathrm{pp}$. 
${ }^{2}$ FRIESEN, V,C. 1984. The spirit of the huckleberry. Univ. of Alberta Press, Edmonton. $145 \mathrm{pp}$.

${ }^{3}$ HOUSTON, STUART. 1980. Wildlife notes. Western Sportsman. 12:16-18.

${ }^{4}$ HOUSTON, C.S., C.J. ESCOTT and R.C. GODWIN. 1982. The Great Gray Owls that weren't. Blue Jay. 40:164-165.

${ }^{5}$ PEARSON, T.G. and others. 1936. Birds of America. Garden City Books, Garden City, N.Y. 272 pp. +271 pp. +289 pp.

${ }^{6}$ PETERSON, R.T. 1941. A field guide to western birds. Houghton Mifflin, Boston. 240 pp.

7 PETERSON, R.T. 1947. A field guide to the birds. Houghton Mifflin, Boston. $290 \mathrm{pp}$.
- PETERSON, R.T., GUY MOUNTFORT and P.A.D. HOLLOM. 1954. A field guide to the birds of Britain and Europe. Houghton Mifflin, Boston. $318 \mathrm{pp}$.

${ }^{9}$ PETERSON, R.T. and E.L. CHALIF. 1973. A field guide to Mexican birds. Houghton Mifflin, Boston. 298 pp.

${ }^{10}$ POUGH, R.H. 1949. Audubon bird guide, eastern land birds Doubleday, Garden $\mathrm{Ci}$ ty, N.Y. 312 pp.

11 POUGH, R.H. 1951. Audobon water bird guide. Doubleday, Garden City, N.Y. 352 pp.

12 POUGH R.H. 1957. Audubon western bird guide. Doubleday, Garden City, N.Y. 316 pp.

13 THOREAU, H.D. 1950. Walden. Harper and Brothers, New York. 440 pp.

\section{GRANTS AVAILABLE FOR CANADIAN BIRD RESEARCH}

The James L. Baillie Memorial Fund for Bird Research and Preservation invites applications for grants to support projects on Canadian birds in 1985. While grants have previously been restricted to Ontario, the fund will now consider applications from other parts of Canada.

The Fund's aim is to encourage field studies by amateur naturalists and to support projects which increase or disseminate knowledge of birds in their natural environment and/or contribute to their preservation. Priority will be given to projects which utilize the efforts of volunteer naturalists in conducting research or fieldwork and to applicants who have little or no access to other sources of support.

Two types of grants will be offered in 1985: (a) Project Grants and (b) Ontario Atlas Fieldwork Grants. Any project which has a volunteer component and otherwise meets the Fund's objectives is eligible for a type (a) grant. Type (b) grants provide partial support for travelling expenses to remote central and northern areas for fieldwork on the Ontario Atlas of Breeding Birds. Requests for funding of atlas projects elsewhere in Canada should be directed to type (a) grants.

Grants do not normally exceed $\$ 1000$. Applications for Project Grants are due by 31 December 1984 and for Atlas Fieldwork Grants by 28 February 1985. All applications should be submitted on forms obtainable from the Secretary. The James L. Baillie Memorial Fund, c/o Long Point Bird Observatory, P.O. Box 160, Port Rowan, Ontario NOE $1 \mathrm{MO}$.

The James L. Baillie Memorial Fund awarded 5 Project Grants totalling $\$ 1,475.00$ and 9 Ontario Atlas Fieldwork Grants totalling $\$ 3,420.80$ in 1984. The Fund is financed in part from proceeds of the Baillie Birdathon. Donations to the Fund are tax deductible and may be sent to the address given above. 